\begin{tabular}{|c|c|c|c|}
\hline & $\begin{array}{l}\text { Escola Superior } \\
\text { de Cestăo e } \\
\text { Tecnologia } \\
\text { [iPSantarém] }\end{array}$ & J & $\begin{array}{l}\text { ISSN 2029-7564 (online) } \\
\text { SOCIALINĖS TECHNOLOGIJOS } \\
\text { SOCIAL TECHNOLOGIES } \\
2014,4(2), \text { p. } 401-413\end{array}$ \\
\hline
\end{tabular}

\title{
SOCIALINIŲ REIŠKINIŲ VERTINIMO INDEKSŲ SUDARYMO YPATUMŲ IR PROBLEMŲ APŽVALGA*
}

\author{
Laura Gudelytè \\ Mykolo Romerio universitetas, Lietuva, 1.gudelyte@mruni.eu \\ Olga Navickienè \\ Mykolo Romerio universitetas, Lietuva, navickiene@mruni.eu \\ Aistè Valentinaitè
}

Kauno technologijos universitetas, Lietuva, aiste.valentinaite@gmail.com

doi:10.13165/ST-14-4-2-12

\section{Santrauka}

Tikslas - išanalizuoti sudètiniu indeksu sudaryma (konstravima) bei socialiniu reiškiniu vertinima sudetiniais indeksais, pagristais rodikliais (indikatoriais) ir ju savybèmis. Norint pasiekti ši tikslą, keliami šie uždaviniai: indikatoriu konstravimo pagrindu ir ju galimu taikymu apžvalga, vertinimo sistemu pranašumų ir trūkumu klasifikacija, atskiru sudètiniu indeksu, taikomu socialiniams reiškiniams vertinti, lyginamoji analizé; duomenu struktūros ir duomenu kokybès įtaka sudètiniu indeksų, taikomu socialiniuose technologijose, suderinamumui aptarimas.

Metodologija - taikomi mokslinès literatūros analizés ir atskiru atveju kokybinès turinio analizes metodai.

Rezultatai - šiame darbe apžvelgti ypatumai ir problemos, su kuriomis susiduriama konstruojant socialiniu reiškiniu vertinimo indeksus. Klasifikuojamos pagrindinès problemos, susijusios su sudètiniu indeksu, taikomu vertinant socialinius reiškinius, konstravimu. Be to, šiame darbe analizuota, kokia ìtaka nekorektiški duomenys ir duomenu struktūra daro sudètinio indekso konstravimui.

\footnotetext{
* Straipsnis parengtas pagal mokslinio tyrimo, finansuojamo Europos socialinio fondo lèšomis pagal visuotinès dotacijos priemonę, medžiagą (projektas „Socialinių technologijų ịtaka kolektyvinio intelekto vystymui tinklo visuomeneje“", projekto kodas VP1-3.1-ŠMM-07-K-03-030“).
} 
Tyrimo ribotumas - šiame straipsnyje pateikiama sudètinių indeksų konstravimo analizé, kuria galima vertinti tik kaip apžvalginę, reikalaujančia išsamesniu tyrimų. Taip pat šiame darbe apžvelgtos pagrindinès su duomenų, naudojamų statistinei analizei, kokybe susijusios problemos ir aptartos galimybès spręsti duomenu trūkumo, statistiniu metodu parinkimo problemos. Siekiant atlikti išsamesnę lyginamaja socialinius reiškinius matuojančiu indeksu analizę, kuri padètu atsakyti i klausima, kurie statistiniai svertiniu koeficientu nustatymo metodai yra patikimesni ir lemia mažesnes matavimo paklaidas, reikalingas tolesnis tyrimas.

Praktinè reikšme - straipsnis gali būti naudingas socialinių reiškinių vertinimo indeksu kūrimui ir egzogeniniu kintamuju (indikatoriu) svertiniu koeficientu nustatymo prielaidoms. Šiame straipsnyje išdèstytos pagrindinès gairès, kuriomis apibrėžiama, kaip gali büti patobulintos sudetiniu indeksu savybès remiantis ekonometriniais metodais, taikomais statistiniam socialinių reiškiniu modeliavimui.

Originalumas / vertingumas - tyrimas yra originalus ir savitu kritiniu požiūriu pagrįsta sudetiniu indeksų konstravimo, duomenu struktūros bei korektiškumo, potencialiu problemu sprendimo büdų analizé.

Raktažodžiai - sudètiniai indeksai, duomenų struktūra, svorių schema.

Tyrimo tipas - bendroji apžvalga.

\section{Ivadas}

Mokslinèje literatūroje (Handbook on Constructing Composite Indicators: Methodology and User Guide, 2008; Saisana ir kt., 2005; Huggins, 2003; Wignaraja ir kt., 2004; HDI, 2004; Freudenberg, 2003) indeksas apibrèžiamas kaip tam tikros srities kiekybinio ar kokybinio vertinimo instrumentas, kurị sudaro subindikatoriai ir kuriuo remiantis analizuojami ịvairaus pobūdžio objektai gali būti tarpusavyje lyginami. Kitaip tariant, indeksai yra dydžiai, kurių reikšmès nustatomos taikant ịvairius statistinius metodus naudojantis statistiniais duomenimis ir savo ruožtu dažnai taikomi kaip ịvesties duomenys stebimo reiškinio analizejje. Indeksų metodu ịprastai ị tam tikrą matavimo sistemą sujungiami atskiri statistiniai dydžiai, kurie gali būti apibūdinami ịvairiomis skalèmis ir skaitinėmis charakteristikomis. Iprastai indeksais prasminga vertinti reiškinius, priklausančius nuo daugelio kintamųju (pvz., šalies, ekonomikos sektoriaus ar organizacijos konkurencingumą, rinkų integraciją, žinių visuomenès plètrą ir t. t.), kurie dèl vertinamo objekto ar reiškinio struktūros ir savo sudetingumo negali būti vienareikšmiškai išmatuojami vienu rodikliu.

Indeksu siekiama vertinamam objektui suteikti glaustą, tačiau išsamų kompleksišką ịvertị, kuris korektiškai atitiktų bendrą objekto būklę. Taikomas vienodos trukmès laikotarpiais ar kitoje reguliarioje matavimo skaleje rodiklis gali nurodyti ilgalaikes stebimo reiškinio raidos tendencijas ar trumpalaikius pokyčius atitinkamoje šalyje ar atitinkamame regione, ir tai gali padèti priimti politinius ar kitokius su valdymu susijusius sprendimus. Be to, indeksai suteikia galimybę ịvertinti ne tik rodiklių reikšmių pokyčius, bet ir jų ittaką vertinamo objekto analizuojamoms savybėms. Indeksų taikymo socialinių reiškinių vertinimo uždaviniuose tikslas - kiekybiškai charakterizuoti jų raidą bėgant 
laikui, tam tikroje teritorijoje ar kokios nors kitos kategorijos (pvz., pagal tam tikrus kriterijus atrinktos gyventojų grupès) atžvilgiu. Pažangiose organizacijose stebimų indeksų reikšmėmis ir jų pokyčiais gali būti grindžiamas sprendimų prièmimas (pvz., finansų rinkų dalyvio elgsena ir pasirinkta investavimo strategija gali priklausyti nuo akcijų ar kitų vertybinių popierių indekso raidos, centrinio banko pinigų politikos sprendimai priklauso nuo vartojimo kainų indeksų raidos bei lygio ir pan.). Indeksai plačiai taikomi vadyboje, planuojant bei analizuojant organizacijos veiklos plano vykdymą, nustatant atskirų veiksnių poveikị stebimų socialinių reiškinių raidai (Lee ir Yu, 2013).

Naujausi moksliniai darbai šioje srityje dažniausiai yra pagrịsti statistiniais metodais, nustatančiais kintamųjų santykinius svorius, kurie atitinka jų reikšmingumą. Nepaisant fakto, kad statistiniais metodais galima pagrịsti vertinamo indekso struktūrą, vis dèlto ne visais atvejais tai pasiteisina, kadangi statistinių metodų taikymas reikalauja tam tikrų prielaidų apie duomenų statistinius pasiskirstymus ir statistinị jų tarpusavio priklausomumą. Šios aplinkybės vertinimo procesą daro sudètingesnį, o tikslumas neretais atvejais nuo to reikšmingai nepadidejja. Pavyzdžiui, van den Endas (2006), konstruodamas bendrą finansinio šalies stabilumo indeksą, nustate, jog skirtumas tarp lygių svorių priskyrimo ir svorių priskyrimo taikant ekonometrinę analizę yra mažas. Be to, paskutiniaisiais metais yra siūloma metodologija, pagrịsta neryškių aibių (angl. fuzzy set) teorijos elementais (Lee ir Yu, 2013; Chiu ir kt., 2004). Neryškioji logika suprantama kaip apibendrintas mokslas apie ịvairius informacijos procesus gamtoje, technologijose ir visuomenejje. Tai yra nepakankamai vienareikšmiai apibrěžta informacijos sąvoka, kuri ịvairių mokslo šakų atstovų interpretuojama ne visais atvejais vienodai. Todèl dažnai psichologinių ir socialinių sistemų veiklos aiškinimų atvejais informacijos terminas keičiamas žiniomis, nes informacija intuityviai suprantama kaip techninių sistemų atributas, o žinios - kaip individo naudojama informacija. Remiantis klasikine (Bulio) logika sprendimų priemimas pagrịstas griežtomis kategorijomis „taip - ne“, be trečiojo sprendimo galimybès. Tai gali būti interpretuojama kurios nors dydžio $X$ savybės kiekybinio vertinimo atskaita atsižvelgiant ị slenkstinị lygị $\theta$, kuris lemia teigiamą ar neigiamą sprendimą. Slenkstinis lygis $\theta$ gali būti vertinamas dviem būdais: pradedant mažomis dydžio $X$ reikšmėmis, jų didejjimo kryptimi, arba didelėmis $X$ reikšmèmis, jų mažejjimo kryptimi. Tačiau informaciniam posistemiui priimant sprendimus pagal tam tikros savybės kiekybinị vertinimą, pagal jo dydị $X$, pasirenkant slenkstị $\theta$ Bulio logikos atvejais, kai situacijos bei savybės vertinamos remiantis priešybėmis ir jų kiekybinių dydžių lyginimu, atsiranda neapibrěžtumų, t. y. atsiranda papildomų būsenų - „neaišku“, „lygu“ poreikis (išsamiau žr. Jasinevičius ir Petrauskas, 2011).

\section{Pagrindinés indeksų savybės ir indeksų sudarymo etapai}

Indeksas yra skaitinè verte, išreiškianti statistinį ryši tarp sumų, susijusių su tuo pačiu reiškiniu. Skaitinè vertẻ suteikia galimybę analizuoti stebimą reiškinị. Kitaip tariant, indeksas yra išvestinè vertinamo objekto ar reiškinio skaitinè charakteristika, apibrèžianti bendrą vertinamo objekto būseną, priklausančią nuo vidinių ir išorinių parametrų. Sudètinis indeksas reiškia, kad jị sudaro sistema atskirų rodiklių, kurių reikšmės atsižvel- 
giant arba ne ị jų svarbą naudojamos vienam galutiniam indeksui nustatyti (Handbook on Constructing Composite Indicators: Methodology and User Guide, 2008). Pagrindiniai sudètinių indeksų taikymo pranašumai ir trūkumai atskleisti Saisana ir Tarantola (2002) parengtame žinyne.

Indekso sudarymo metodika apima tris struktūrinius elementus: dimensijas, komponentes bei indikatorius (žr. 1 pav.). Dimensijos apima svarbiausias socialinị reiškinị apibrěžiančias kategorijas. Sudètinio indekso struktūra gana aiškiai rodo, kaip ịvairūs indikatoriai skiriasi atskirose dimensijose. Todèl naudojama informacija iš esmès nèra prarandama ir kiekvienoje atskiroje dimensijoje gana aiškiai atskleidžiama. Kita vertus, net jei atskiro indikatoriaus reikšmès skirtingiems vertinamiems objektas skiriasi, negalime jų korektiškai reitinguoti (De Muro ir kt., 2009). Aprašant socialinius reiškinius dažnai taikomi trijų dimensijų indeksai (Resindex, 2013; Social Progress Index 2014 Methodological Report, 2014; Foa ir Tanner, 2012; Human Development Index, 2014). Kiekvieną dimensiją sudaro kelios unikalios tarpusavyje susijusių sąvokų komponentès. Kiekviena komponente sudaryta iš indikatorių, matuojančių kiek įmanoma daug svarbių komponentès aspektų.

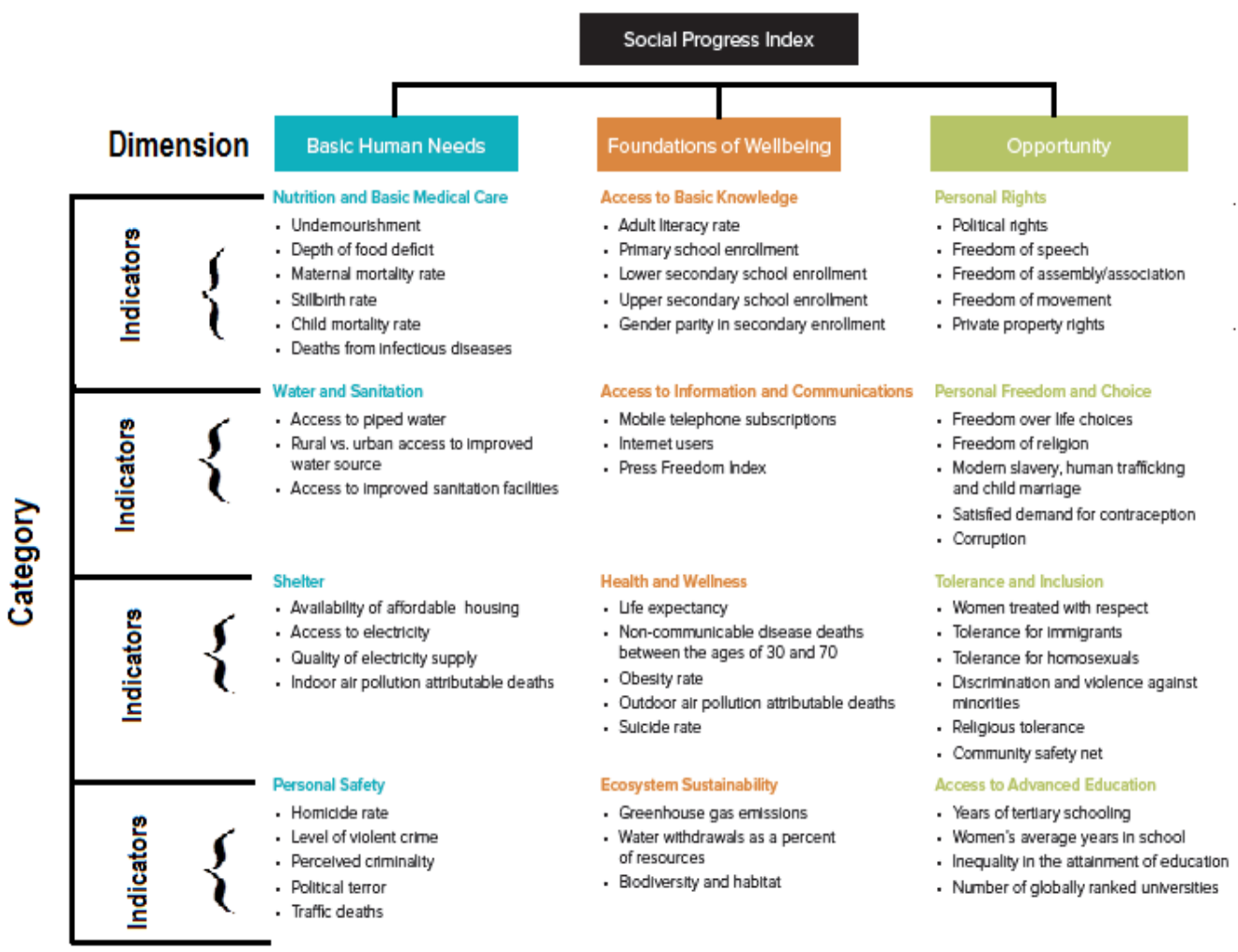

1 pav. Tipinè sudètinio indekso struktūra

Šaltinis: Social Progress Index 2014 Methodological Report. 2014. The Social Progress Imperative. Washington, 2014. 
Dažnai indikatoriai agreguoti taikant svertinị vidurkị (Diener ir Suh, 1997; Newey ir Stoker, 1993), o svertiniai koeficientai nustatomi faktorinės analizės metodu. Tradiciniai indekso kūrimo metodai, faktorinès analizès ir reflektyvaus modeliavimo, negali būti taikomi, kai ị indeksą yra įtraukti įvairaus pobūdžio rodikliai, kurie silpnai koreliuoja tarpusavyje, todèl šie indikatoriai analizuojami atskirai vienas nuo kito (van Beuningen ir Schmeets, 2013).

Indekso kokybė priklauso ne tik nuo pasirinktos konstravimo metodologijos, bet ir nuo jo struktūros bei naudojamų duomenų korektiškumo. Pastebima, kad daugelis naujų metodinių pasiūlymų, susijusių su indeksų skaičiavimu ar vertinimu, taip ir lieka tik eksperimentiniai (Booysen, 2002), nepatikrinti kitų autorių. Taigi, pateikiama indeksu skaičiavimo metodika straipsniuose dažnai kelia abejonių, nes patikrinimas, kaip ir naujos indeksų skaičiavimo metodikos sudarymas bei jos realizavimas, reikalauja daug žmogiškųjų resursų. Nepaisant to, daugelio indeksų skaičiavimo metodikos yra tobulinamos (Noorbakhsh, 1998), o kai kurių indeksų - atnaujinamos kiekvienais metais (Human Development Index, 2014). Indekso konstrukcijos sudarymo loginè schema atrodo taip (žr. 2 pav.):

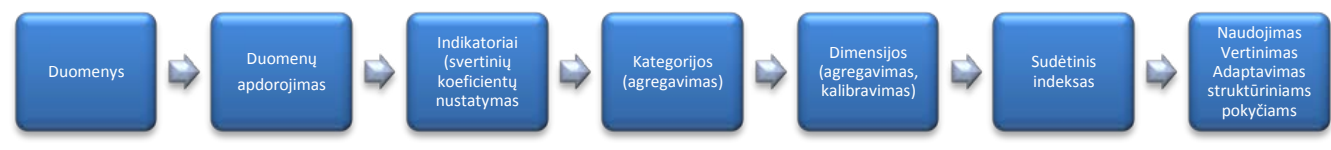

2 pav. Sudètinio indekso kūrimo procesas

Šaltinis: sudaryta autorių.

\section{Duomenų apdorojimas}

Remiantis statistiniais metodais sukonstruoti indeksai gali priklausyti nuo įvairaus kiekio ir pobūdžio kintamųjų, kurių reikšmès charakterizuojamos duomenimis. Apskritai indeksams vertinti naudojamų duomenų specialiai apdoroti nereikia - viską lemia pasirinkti statistiniai metodai ir turimų duomenų kokybẻ bei prigimtis. Prieš konstruojant indikatorių turi būti išsamiai ištirtas pagrindinis surinktų duomenų pobūdis, kad būtų galima daryti tinkamas išvadas nustačius indikatoriaus reikšmes. Dažnai praktiniai skaičiavimai nesuteikia pagrindo daryti vienareikšmių išvadų, todẻl pirminiai duomenys turi būti atitinkamai susisteminti. Pavyzdžiui, vienais atvejais pakanka duomenis tarpusavyje lyginti juos agreguojant ar taikant aprašomosios statistikos metodus: variacinès eilutès, grupavimo ir lentelių sudarymo būdais, kitais atvejais būtina taikyti, pvz., regresinę, faktorinę ar klasterių analizę bei kitus metodus. Tačiau net ir išsamiais statistiniais duomenimis pagrịstam indeksui įtaką daro neapibrèžtumas, ir šiai kategorijai ịprastai atliekamos atitinkamos prielaidos pasirenkant modeliavimo metodus. Tačiau dèl painios duomenų struktūros ir statistinio modelio, kuriuo apibrèžiamos statistinès parametrų savybės, konstrukcijos sudètiniai indeksai gali būti sunkiai interpretuojami.

Kita problema konstruojant indeksus - kintamųjų reikšmingumo, kitaip dar suprantamo kaip santykinè svarba, apibréžiamo svertiniais koeficientais, nustatymas. Vienaip ar kitaip apibrèžtų svertinių koeficientų priskyrimas atitinkamam kintamajam, kuris gali 
būti charakterizuojamas kaip atsakymas ị apklausoje pateiktą klausimą, yra apibrèžiamas sudètinio indekso modelyje. Nemaža dalis indikatorių, sudarančių sudètinị indeksą, yra kombinacijos atsakymų ị pagal tam tikras temas ir kitus požymius sugrupuotus klausimus.

Svertinių koeficientų nustatymas yra gana sudėtingas procesas. Svarbu pabrèžti, kad dèl ekspertinio vertinimo daugiau ar mažiau išlieka subjektyvumo rizika. Siekiant kuo tiksliau statistiniais metodais įvertinti stebimo proceso charakteristikas, taikomos skirtingos svertinių koeficientų suteikimo metodikos:

- kai visiems veiksniams suteikiami vienodo dydžio svorio koeficientai;

- kai svertiniai koeficientai suteikiami veiksnių grupems;

- kai svertiniai koeficientai suteikiami veiksnių pogrupiams;

- kai svertiniai koeficientai suteikiami visiems veiksniams.

\section{Normavimas (angl. normalization)}

Kadangi indeksais ir kitais indikatoriais analizuojamos objektų savybės gali būti apibūdinamos skirtingomis reikšmėmis, atsiranda poreikis suformuoti korektišką vertinimo procedūrą, kuri suteiktų galimybę skirtingus rodiklius korektiškai lyginti tarpusavyje (Chakravarty, 2003). Todèl siekiant sujungti kintamuosius ị bendrą indeksą kiekvieno rodiklio reikšmé yra normalizuojama (Caselli, 2008; Ray, 2008). Taip sukuriama galimybẻ lyginti skirtingo masto subjektų, tačiau to paties reiškinio rodiklių reikšmes bei atlikti kompleksišką tyrimą. Ne mažiau svarbu pasirinkti tinkamiausią normalizavimo metodą, taikytina nagrinejjamai problemai, atsižvelgiant ne tik ị metodo savybes, bet ir ị indikatorių matavimo vienetus, $\mathfrak{i}$ jų atsparumą galimiems duomenų iškraipymams (Ebert ir Welsch, 2004). Skirtingi normavimo metodai lemia skirtingus sudetinio indikatoriaus rezultatus.

Skirtingų normavimo metodų taikymas gali sukelti šias problemas:

- duomenų normavimas pagal atstumo nuo grupés maksimalaus elemento metodą gali stipriai paveikti galutinị rezultatą;

- normuojant duomenis pagal atstumo nuo vidurkio metodą, vieno kintamojo vidurkio stiprus viršijimas ar atsilikimas nuo vidurkio pagal vieną rodikli gali daryti didelę įtaką galutiniam rezultatui.

Normavimas remiantis standartinio nuokrypio nuo vidurkio ir atstumo nuo minimalios ir maksimalios reikšmės metodais tokių problemų nesukelia.

Dažniausiai taikomi šie normavimo metodai: standartinio nuokrypio nuo vidurkio (angl. standard deviation from the mean), atstumo nuo minimalios ir maksimalios reikšmès, atstumo nuo grupès lyderio ar nuo vidurkio. Žymiai rečiau taikomas procentiliu metodas (Foa ir Tanner, 2012). Procentilių metodas - tai procentilių skalès bei vienmatès ir dvimatés procentilių diagramos, kuriomis vertinami stebimo objekto būklès indikatoriai. Taikant šį metodą, tiriamojo indikatoriaus stebimos reikšmès didejimo tvarka surikiuojamos variacineje eiluteje, kurią procentiliai padalina ił 100 intervalų, bei nustatomi kiekvieno jų vidurkiai. 50-as procentilis sutampa su mediana. Žymesnius tiriamojo rodiklio pokyčius atskleidžia trečias, dešimtas, 25 -as, 50-as, 75 -as, 90 -as, 97 -as procentiliai. Atliekant indikatoriaus matavimus, gauti rezultatai iprastai fiksuojami augimo diagramose ir braižoma pokyčių kreivè (Elveback ir Taylor, 1969). 


\section{Matavimo skalès}

Socialiniai tyrimai gali būti klaidingi, jei tyrimo sąvokos nebūtų tinkamai apibrèžtos matematinès statistikos terminais ir ịvertintos (išmatuotos) (Bailey, 2008). Matavimo skalès yra požymių reikšmių matavimo būdai, skirti ịvairaus pobūdžio dydžiams įvertinti, išmatuoti (Diamantopoulos ir Winklhofer, 2001). Tais atvejais, kai skalès apibréžiamos skaičiais, statistinių metodų taikymas nesukelia jokių kliūčių. Kiek sudètingiau interpretuoti kokybinio pobūdžio informaciją taikant kiekybinius metodus, nes nèra akivaizdu, kaip apibrèžiamas atstumas, .y. skirtumas tars skirtingų objektų. Tokiais atvejais tiriamasis objektas matuojamas taikant nominaliąsias bei rangines matavimo skales (McGranahan, 1995). Kartais rangų skalè skirta ir kiekybiniams kintamiesiems išmatuoti. Intervalu bei santykinès matavimo skalès skirtos tik kiekybiniams požymiams išmatuoti.

\section{Trūkstami duomenys (angl. missing data)}

Duomenų trūkumas statistinèje analizèje yra didelè problema, nes ị juos neatsižvelgus galima gauti iškreiptus ir netikslius rezultatus tais atvejais, kai indikatoriaus konstrukcija yra statistiškai patikima. Ši problema gali būti sprendžiama ne kuriant statistinị modelị, bet duomenų paruošimo statistiniam modeliavimui metu (Miller ir Salkind, 2002). Šiuo atveju nepageidaujama vietoj trūkstamų duomenų ịterpti ekstremalias stebimo atsitiktinio dydžio reikšmes, nes jos gali reikšmingai iškreipti ịverčius.

Kita vertus, neretai sprendžiant realias problemas dalis informacijos dingsta. Taikant tradicinius metodus, elgiamasi dvejopai: trūkstama informacija ignoruojama arba trūkstamos reikšmės pakeičiamos vidutinėmis ar tam tikromis konkrečiam kintamajam būdingomis reikšmėmis. Šie metodai tinka tais atvejais, kai trūksta tik kelių reikšmių. Tačiau, jeigu trūksta reikšmingesnès dalies duomenų, minėtieji metodai gali iškraipyti modeliavimo rezultatus. Šiai problemai išspręsti autoriai siūle procedūrą, kuri, taikant neuroninius tinklus ar simuliacijos metodus duomenų transformacijai, ịvertina trūkstamas reikšmes (išsamiau, pvz., Rubright ir kt., 2014).

\section{Išskirčių duomenyse apdorojimas}

Diagnostiniai tyrimai tikrinant atitinkamas statistines hipotezes suteikia galimybiu nustatyti išskirtis duomenyse, siekiant nustatyti atsitiktinių dydžių, aprašančių kintamuosius, standartinius nuokrypius reikšmių, išsidėsčiusių už normalaus skirstinio atitinkamo pasikliovimo lygmens pasikliautinio intervalo. Tačiau vien tik toks testas ne visais atvejais būna pakankamas ir neapsaugo galutinio rezultato nuo stiprių iškraipymų. Tokia analizė gali būti papildyta statistiniais testais, apibūdinančiais statistinị reikšmingumą (ịtaką) ir svertą, kurie suteikia galimybę nustatyti, kokio masto įtaką kiekvienam iš rodiklių daro kintamųjų išskirtys dẻl neteisingai pateiktų duomenų ar matavimo paklaidų. Tokia analizė padeda nustatyti tuos duomenis, kuriuos būtina pašalinti prieš taikant statistinius metodus. 


\section{Standartiniai nuokrypiai}

Vienas iš tokių bandymų nustatyti išskirtis yra standartinio nuokrypio matavimas. Normaliai pasiskirstęs atsitiktinis dydis, kurio 99,7 \% reikšmių yra nutolusios per 3 standartinius nuokrypius nuo vidurkio. Kiekvienas kintamasis tiriamas atskirai, siekiant nustatyti, kurios reikšmés nuo vidurkio nutolusios daugiau ar mažiau už 3 standartinius nuokrypius. Siekiant tai patikrinti būtina transformuoti normaliai pasiskirsčiusius atsitiktinius dydžius ị standartinius normalius.

Kadangi neretai stebimų atsitiktinių dydžių reikšmės nėra pasiskirsčiusios pagal normalųji dėsni, siekiant nustatyti žymius nuokrypius ir ekstremalias reikšmes duomenyse, be grafinès ir kvantilių analizès, dar taikomi neparametriniai standartinio nuokrypio testai (pagrịsti Čebyševo nelygybe, žr., pvz., Kubilius, 1996). Kita vertus, ekstremalių reikšmių ir didelių nuokrypių egzistavimas nebūtinai reiškia, kad duomenys yra neadekvatūs. Kadangi ekstremalios reikšmès yra pasiskirsčiusios netipiškai, t. y. už normaliojo skirstinio „uodegų“, testai nustato jų neadekvatumą normaliajam dėsniui.

\section{Svertas}

Sverto taškai apibrèžia vietą imties duomenyse, kurioje gali ịvykti struktūrinių stebimų reiškinių pokyčiai. Netipinès atsitiktinio dydžio reikšmės turi didesnị svertą. Nors pavienès išskirtys ir nedaro didelès įtakos regresijos koeficientams, tačiau jos turi įtakos modelio kokybei: reikšmingumui ir paklaidų lygiui. Parenkant ir apdorojant statistinius duomenis siekiama, kad atskiro indikatoriaus ittaka sudètiniam indeksui atitiktų imties duomenis. Šiuo atveju įtaka sudètinio indekso reikšmei reiškia ir egzogeninių kintamųjų, ir indikatorių poveikį. Vienas iš dažniausiai taikomų kiekvieno duomenų elemento įtakos matų yra Cooko atstumas, išreiškiamas formule

$$
D_{i}=\frac{\left(\widehat{\beta_{(l)}}-\hat{\beta}\right) X^{\prime} X\left(\widehat{\beta_{(l)}}-\hat{\beta}\right)}{p \cdot M S E} ;
$$

čia $X$ - egzogeninių kintamųjų matrica, $\beta$ - regresijos lygties parametrų vektorius, $\hat{\beta}$ regresijos lygties parametrų i̇verčių vektorius, MSE - vidutinė kvadratinė paklaida, $p$ - regresijos parametrų skaičius.

\section{Struktūriniai pokyčiai}

Stebimą objektą kartais ištinka ịvairios krizès, pasitaiko stichinių nelaimių ar kitokių reiškinių, kurie iš esmès paveikia reiškinio ar objekto elgseną. Tokie pokyčiai gali būti pastebimi taikant specialius testus atitinkamų rodiklių laiko eilutese, kurių elgsena po tam tikros krizès ar stichinès nelaimės gali keistis iš esmès. Toks pasikeitimas vadinamas struktūriniu. Tačiau dažnai pasitaiko atvejų, kai plika akimi sunku ižiūreti esamus struktūrinius pokyčius, todèl šios problemos sprendžiamos taikant specialius testus struktūriniams pokyčiams nustatyti (Andrews, 1993; Ali ir kt., 1997). 


\section{Lyginamoji socialinių indeksų analize}

Kaip socialinių reiškinių vertinimo pavyzdžius toliau straipsnyje lyginsime tris indeksus: socialinès plètros indeksą (angl. Social Development Index, SDI) (išsamiau žr. Foa ir Tanner, 2012), socialinès pažangos indeksą (angl. Social Progress Index, SPI) (išsamiau žr. Social Progress Index, 2014) ir regioninị socialinių inovacijų indeksą (angl. Regional Social Innovation Index, RESINDEX) (išsamiau žr. Resindex: Regional Social Innovation Index, 2013). Socialinès plètros indekso, socialinės pažangos indekso ir regioninio socialinių inovacijų indekso schemos yra panašios, atitinkančios indeksų sudarymo teorinius principus. Visi šie indeksai yra sudètiniai, turintys po keletą dimensijų, kuriose atskiriems indikatoriams priskirti svertiniai koeficientai. Tačiau jais bandoma ịvertinti skirtingus reiškinius. Visi šie indeksai gali būti taikomi globaliai. Globaliai taikomu indeksu siekiama nustatyti, kaip šalys, kaip visuma, atitinka tam tikrus socialinius kriterijus, išreikštus rodikliais Tai svarbu ir naudinga lyginant šalis tarpusavyje ir suteikia galimybę nustatyti kiekvienos šalies pažangos ir atsilikimo mastą siekiant suformuoti geriausią praktiką ir tikslines sritis, kurias būtina tobulinti.

Socialinès plètros indeksas (angl. Social Development Index, SDI). Socialinès plètros indeksą sudaro 6 dimensijos, apimančios pilietinị aktyvumą, klubus ir asociacijas, sanglaudą, tarpasmeninị saugumą ir pasitikejjimą, lyčių lygybę bei mažumų ịtraukimą. Konstruojant socialinès plètros indeksą taikytas procentilių metodas, kuriuo išsprendžiamos problemos, susijusios su statistinemis paklaidomis dèl imties ribotumo ir nereprezentatyvumo (Foa ir Tanner, 2012). Šis metodas naudingas tuo, kad suteikia galimybę paeiliui pridèti naujus rodiklius, net iš labai mažų imčių, neprarandant indekso korektiškumo. Be to, tai suteikia galimybių nuolat tikslinti šalims suteiktus ịverčius (angl. country scores), naudojant informaciją apie atitinkamą jų padètị rangų skaleje.

Yra keletas išsamių ne vienai šaliai taikomų indeksų, kuriais remiantis formuojama politika, kuria reguliuojami socialiniai reiškiniai bei taikoma atitinkama praktika, susijusi su valstybės politika igyvendinant, pvz., pilietinès visuomenés plètrą, tarpgrupinę sanglaudą arba mažinant lyčių diskriminaciją. Socialinès plètros indeksais agreguojami ịvairūs galimų socialinių institucijų duomenys ị keletą tarpvalstybinių tyrimų. Socialinès plètros indeksas sudaryti iš daugiau nei 200 rodiklių iš 25 šaltinių, ịskaitant tarptautines organizacijas, lyginamųjų tyrimų projektus, reitingų agentūrų vertinimus. Taip pat duomenų agregavimui taikant procentilių metodą, skirtingai nei regresinès analizès atveju, neatsiranda sunkumų nustatant svertinius koeficientus, kai imties dydis yra labai mažas. Tai aktualu konstruojant tokio pobūdžio indeksus, kurių ịverčiams nustatyti naudojami negalutiniai duomenys, ir dar reikia pridèti naujus rodiklius, kai duomenys tampa prieinami, net jei yra nereikšmingi.

Socialinès pažangos indeksas (angl. Social Progress Index, SPI). Socialinès pažangos indekso sistema taikoma siekiant nustatyti visuomenès socialinio išsivystymo lygị ir prielaidas visuomenès nariams siekti gerovès. Juo tiesiogiai matuojama visuomenès gerovè ir galimybès toliau ją vystyti. Jis yra sudarytas iš trijų dimensijų: būtinų esminių žmogaus poreikių, gerovès pagrindų ir galimybių. Šio indekso reikšmès, kaip ir daugumos ji sudarančių indikatorių, patenka ị intervalą $[0,100]$, nes taip siekiama rodikliams suteikti aiškią viršutinę ir apatinę ribą. Kita vertus, yra keletas išimtinių atvejų, kai indikatorių reikšmių skalè yra kitokia, pvz., šiltnamio efektą sukeliančių dujų emisija neturi ex ante nustatytos viršutinès ribos. 
Regioninis socialinių inovacijų indeksas (angl. Regional Social Innovation Index, RESINDEX), sukurtas Socialinių inovacijų centro „Sinnergiak“. Šiuo indeksu matuojama ne toks savo turiniu gana platus objektas kaip bendruomenès gerové, o tik tam tikras objektas: jos pasirengimas socialinèms inovacijoms. Šiuo indeksu siekiama vertinti ịvairių organizacijų intelektinę brandą, reikalingą inovacijoms kurti. Regioninis socialinių inovacijų indeksas sudarytas iš 3 dimensijų: potencialių inovacijų gebejimų indeksas, socialinès orientacijos indeksas, socialinių inovacijų indeksas. Duomenys šiam indeksui gaunami apklausiant respondentus. Kaip žinoma autoriams, šis indeksas yra išbandytas Baskijos regione Ispanijoje, tačiau dar nèra aiškūs rezultatai, susiję su kitų šalių regionų situacija. Atitinkamų kintamųjų indikatorių reikšmės nustatomos taikant normavimo formules. Be to, atitinkamiems indikatoriams išvestos formulès pritaikytos skirtingų tipu organizacijoms (verslo ịmonèms, universitetams, kitoms ne pelno siekiančioms organizacijoms). Iš pateiktų formulių nèra akivaizdu, kad visi indikatoriai igyja reikšmes intervale $[0,1]$, tačiau kadangi igyja teigiamas reikšmes, problemos dẻl korektiško skirtingu regionų lyginimo išnyksta. Kita vertus, pats RESINDEX indeksas igyja reikšmes nuo 0 iki 100 ir taip suteikia galimybę reitinguoti regionus pagal jų potencialą socialinėms inovacijoms.

\section{Išvados}

Sudètiniai indeksai yra naudingi vadybos ir sprendimų prièmimo teorijose, plačiai taikomi praktikoje, ne tik statistiškai pagrindžiant sprendimus, bei ir kaip stebėsenos priemonè.

Sudètinio indekso struktūra gana aiškiai rodo, kaip įvairūs rodikliai skiriasi atskirose dimensijose. Todèl sudètinis indeksas turi keletą pranašumų: naudojama informacija iš esmès nèra prarandama ir kiekvienoje atskiroje dimensijoje gana aiškiai atskleidžiama. Kita vertus, sudètinis indeksas turi ir trūkumų: net jeigu atskiro indikatoriaus reikšmès skirtingiems vertinamiems objektams skiriasi, negalime jų korektiškai reitinguoti (De Muro ir kt., 2009). Be to, dar vienas argumentas prieš sudètinių indeksų taikymą grindžiamas faktu, kad jie ịprastai neatskleidžia papildomos informacijos, kuri gali būti pateikiama vienu indeksu, tačiau reikalauja žymiai daugiau duomenų analizei atlikti.

Be daugybès aiškių pranašumų, statistiniais metodais ir duomenimis pagrịsti indeksai ne visada atitinka realią stebimo proceso būseną, kadangi jų reikšmės priklauso nuo ịvesties duomenų. Duomenų korektiškumas lemia indekso korektiškumą. Tokios problemos sprendžiamos darant atitinkamas heteroskedastiškumo prielaidas statistinių modelių triukšmui (t. y. duomenų daliai, kuri nèra stebima ir kuriai atliekamos prielaidos pasirenkant statistinès analizės modelį), generuojant trūkstamas reikšmes ar kitaip agreguojant duomenis.

Kaip ir daugeliu statistinès analizės atvejų, reikšminga problema taikant socialinius indeksus išlieka duomenų trūkumas arba jų nekorektiškumas. Be to, sudètinga indeksus lyginti tais atvejais, kai vyksta esminiai struktūriniai stebimų objektų ar reiškinio pokyčiai, tačiau ir šiais atvejais yra sukurta nemažai statistinių metodų, kuriais sprendžiami struktūrinių pokyčiu (angl. change point, structural change) ar epideminių pokyčių (angl. epydemic change) uždaviniai atsitiktiniams procesams. 


\section{Literatūra}

Ali, O. G.; Faltin, F. W.; Doganaksoy, N. 1997. Practical Change Point Estimation. Technical Information Series. General Electric Company, Research and Development Center.

Andrews, D. W.; Andrews K. 1993. Tests for Parameter Instability and Structural Change with Unknown Change Point. Econometrica, 61(4): 821-856.

van Beuningen, J.; Schmeets, H. 2013. Developing a Social Capital Index for the Netherlands. Social Indicators Research, 113(3): 859-886.

Booysen, F. 2002. An Overview and Evaluation of Composite Indices of Development. Social Indicators Research, 59(2): 115-151.

Bruneckienè, J.; Činčikaite, R. 2009. Šalies regionų konkurencingumo vertinimas regionu konkurencingumo indeksu: tikslumo didinimo aspektas. Ekonomika ir vadyba, 14: 700-708.

Caselli, M. 2008. Measuring... what? Notes on some globalization indices. Globalizations, 5(3): 383-404.

Chakravarty, S. R. 2003. A Generalized Human Development Index. Review of development economics, 7(1): 99-114.

Chiu, YC.; Shyu, JZ.; Tzeng, GH. 2004. Fuzzy MCDM for Evaluating the E-commerce Strategy. International Journal of Computer Applications in Technology, 19(1): 12-22.

Diamantopoulos, A.; Winklhofer, H. M. 2001. Index Construction with Formative Indicators: An alternative to Scale Development. Journal of Marketing Research, 38(May): 277-290.

Diener, E.; Suh, E. 1997. Measuring quality of life: Economic, social, and subjective indicators. Social indicators research, 40(1-2): 189-216.

Ebert, U.; Welsch, H. 2004. Meaningful Environmental Indices: a Social Choice Approach. Journal of Environmental Economics and Management, 47(2): 270-283.

Elveback, L. R.; Taylor, W. F. 1969. Statistical Methods of Estimating Percentiles. Annals of the New York Academy of Sciences, 161(2): 538-548.

Foa, R.; Tanner, J. C. 2012. Methodology of the Indices of Social Development. International
Institute of Social Studies of Erasmus University Rotterdam [interactive]. Hague, 2014 [accessed 2014-08-10]. <http://www. indsocdev.org/resources/Methodology\%20 of $\% 20$ the $\% 20$ Social $\% 20$ Development $\% 20$ Indices_\%20jan11.pdf>.

Freudenberg, M. 2003. Composite Indicators of Country Performance: A Critical Assessment. STI Working Paper, 2003(16): 2-34.

Handbook on Constructing Composite Indicators: Methodology and User Guide. 2008. The Organisation for Economic Co-operation and Development [interactive]. [accessed 201408-29]. <http://www.oecd.org/std/42495745. pdf $>$.

(HDI). United Nations Development Programme [interactive]. 2014 [accessed 2014-08-10]. $<$ http://hdr.undp.org/en/content/humandevelopment-index-hdi-table $>$.

Bailey, K. 2008. Methods of social research. New York: Simon and Schuster.

Huggins, R. 2003. Creating a UK Competitiveness Index: Regional and Local Benchmarking. Regional Studies, 37(1): 89-96.

Jasinevičius, R.; Petrauskas, V. 2011. Sprendimų pagrindimo kompiuterizavimas. Kauno technologijos universitetas. Kaunas: Technologija.

Kubilius, J. Tikimybių teorija ir matematinè statistika. Vilnius, 1996.

Lee, SK.; Yu, JH. 2013. Composite Indicator Development Using Utility Function and Fuzzy Theory. Journal of the Operational Research Society, 64(8): 1279-1290.

McGranahan, D. 1995. Measurement of Development: Research at the UN's Research Institute for Social development. International Social Science Journal, 143: 39-57.

Miller, D. C.; Salkind, N. J. 2002. Handbook of research design and social measurement. Thousand Oaks: Sage.

De Muro, P.; Mazziotta, M.; Pareto, A. 2009. Composite Indices for Multidimensional Development and Poverty: An Application to MDG Indicators. Wye City Group Meeting [interactive]. Rome, 2009 [accessed 201410-01]. <http://www. fao. org/es/ess/rural/ wye_city_group $>$. 
Newey, W. K.; Stoker, T. M. 1993. Efficiency of Weighted Average Derivative Estimators and Index Models. Econometrica: Journal of the Econometric Society, 1199-1223.

Noorbakhsh, F. 1998. A Modified Human Development Index. World Development, 26(3): 517-528.

Ray, A. K. 2008. Measurement of Social Development: An International Comparison. Social Indicators Research, 86(1): 1-46.

Resindex: Regional Social Innovation Index. 2013. SINNERGIAK Social Innovation (UPV/ EHU), Innobasque - 2013, Basque Innovation Agency [interactive]. [accessed 2014-08-07]. $<$ http://www.sinnergiak.org/wp-content/uplo ads/2014/06/cuaderno_resindex_cast.pdf $>$.

Rubright. J. D.; Nandakumar, R.; Glutting, J. J. 2014. A Simulation Study of Missing Data with Multiple Missing X's. Practical Assessment, Research and Evaluation, 19(10).

Saisana, M.; Tarantola, S. 2002. State-of-theart Report on Current Methodologies and Practices for Composite Indicator Development. EUR 20408 EN, European Commission-JRC: Italy.
Saisana, M.; Tarantola, S.; Schulze, N.; Cherchye, L.; Moesen, W.; Van Puyenbroeck, T. 2005. Knowledge Economy Indicators. State-of-theArt Report on Composite Indicators for the Knowledge-based Economy. Workpackage 5, 54 p. [interactive]. [accessed 2014-08-30]. $<$ http://kei.publicstatistics.net/KEI\%20D5_1. pdf $>$.

Social Progress Index. 2014. Methodological Report. 2014. The Social Progress Imperative [interactive]. Washington, 2014 [accessed 2014-08-10]. <http://www.socialprogressim perative.org/publications $>$.

The World Competitiveness Yearbook 2004. Lausanne: International Institute for Management Development [interactive]. 2014 [accessed 2014-08-30]. <http://www02.imd. $\mathrm{ch} / \mathrm{wcc} /$ pressreleases $>$.

van den End, J. W. 2006. Indicator and Boundaries of Financial Stability. De Nederlandsche Bank NV. Working Paper 097(2006).

Wignaraja, G.; Lezama, M.; Joiner, D. 2004. Small States in Transition: From Vulnerability to Competitiveness. United Kingdom: Commonwealth Secretariat.

\title{
OVERVIEW OF FEATURES AND ISSUES IN DESIGNING EVALUATION INDICES FOR SOCIAL PHENOMENA*
}

\author{
Laura Gudelyte \\ Mykolas Romeris University, Lithuania, 1.gudelyte@mruni.eu \\ Olga Navickienè \\ Mykolas Romeris University, Lithuania, navickiene@mruni.eu \\ Aistè Valentinaitè \\ Kaunas University of Technology, Lithuania, aiste.valentinaite@gmail.com
}

\section{Summary}

The purpose of this paper is to analyse the design (construction) of composite indices and the evaluation of composite indices for social phenomena based on indicators and their properties. In order to achieve this objective, the following tasks were set: an overview of

The research is funded by European Social Fund under the measure „Support to Research Activities of Scientists and Other Researcher (Global Grant)“ administrated by Lithuanian Research Council (grant No. VP1-3.1-ŠMM-07-K-03-030, name of the project "Social Technologies for Developing Collective Intelligence in Networked Society"). 
the basics of the construction of indicators and their possible applications, the classification of advantages and disadvantages of evaluation systems, the composite indices and indicators applied in measuring characteristics of social phenomena; defining the impact of the data structure and quality of data on the coherence of composite indices applied in social technologies. The features and issues in designing the composite indices measuring the social phenomena were discussed. The main problems concerning the construction of composite indices applied evaluating social phenomena were classified. In addition, the dependence of coherence of composite indices on the used data and their structure was discussed in this paper.

This paper is useful for designing evaluation indices for social phenomena and assumptions on weighting of exogenous variables. It sets out the basic guidelines that can be developed in the future based on econometric approaches applied to statistical modelling of social phenomena.

Keywords: composite indices, data structure, weighting scheme. 